\title{
CONTEXTUALIZATION OF SULUK CANDRA'S CHARACTER VALUES
}

\author{
Moch. Lukluil Maknun, Umi Muzayanah \\ Office of Religious Research and Development, Ministry of Religious Affairs \\ of the Republic of Indonesia, Semarang, Indonesia \\ lukluilmaknun84@gmail.com \\ umimoza78@gmail.com
}

\begin{abstract}
Indonesia's education is heavily focusing on developing students' good characters. Character values can be explored from the legacy of the previous generations through old scriptures. Of many genres of Javanese scriptures containing character values are the wulang scripts, such as Suluk Candra, written by Prince Wijil Kadilangu and stored in Museum Rekso Pustaka Mangkunegaran Library. This article explores the character values depicted by the manuscript and contextualizes them with today's education. The present study employs the principles of philology and the interpretation of texts. The working principle of philology aims to produce a text edition, while interpretation aims to analyze the content of the text. It is found that Suluk Candra is a script containing Islamic values, teaching at least four ethics that can be contextualized with the world of education in the current 4.0 era. On the ethical values, there are ethics to the king/ leader/ state, ethics to teachers, ethics to fellow human beings, and ethics to oneself. Besides, there are also values of character education in Suluk Candra. Those character values are relevant to the present day, including the love of science, logical thinking, critical, creativity, innovation, religiosity, honesty, and nationalism.
\end{abstract}

Keywords: Character Values, Interpretation, Suluk Candra script 


\begin{abstract}
Abstrak
Dunia pendidikan Indonesia sedang menggalakkan pendidikan yang berkarakter. Menggali nilai karakter warisan generasi pendahulu dapat ditelusur melalui naskah. Di antara genre naskah di Jawa yang sangat kaya nilai karakter adalah naskah wulang, seperti naskah Suluk Candra karya Pangeran Wijil Kadilangu yang tersimpan di Perpustakaan Museum Rekso Pustaka Mangkunegaran. Artikel ini berusaha menggali nilai-nilai karakter yang ada di dalamnya serta mencoba mengkontekstualisasikan dengan dunia pendidikan saat ini. Prinsip kerja filologi dan interpretasi teks adalah metode yang dimanfaatkan dalam kajian ini. Prinsip kerja filologi bermuara untuk menghasilkan edisi teks, sedangkan interpretasi bertujuan menganalisis kandungan isi teks. Adapun hasil kajian ini sebagai berikut. Suluk Candra ini merupakan naskah wulang yang bermuatan nilai keislaman. Setidaknya suluk ini mengajarkan empat etika yang dapat dikonteskkan dengan dunia pendidikan di era 4.0 saat ini. Temuan etika tersebut yaitu, etika kepada raja/pimpinan/negara, etika kepada guru, etika kepada sesama manusia, dan etika kepada diri sendiri. Selain nilai etika, dalam Suluk Candra juga ditemukan nilainilai pendidikan karakter yang relevan dengan masa sekarang di antaranya cinta ilmu, berpikir logis, kritis, kreatif, inovatif, religius, jujur, dan nasionalis.
\end{abstract}

Kata Kunci: Nilai Karakter, Interpretasi, Naskah Suluk Candra

\title{
Introduction
}

Character education has been promoted as a national movement by the Ministry of Education of Indonesia, aiming at preparing students to be human beings who believes in God, is noble, healthy, knowledgeable, capable, creative, independent to become democratic and responsible citizens (Presidential Decree No. 87 of 2017). Character values can be traced back to ancient wisdoms and legacies of Nusantara, as recorded in its manuscripts. Indonesia (Nusantara) is rich in languages and scripts, among which is represented in ancient manuscripts and VOL. 9 NO. 1 JUNE 2020 
believed to contain a lot of valuable educational values.

This study aims to explore character values from a Javanese manuscripts in the Surakarta Kartasura Residency, compiled in catalogs by Western manuscripts such as Nancy Florida (1993, 2000) and by the depository agency. The compiled catalog, no matter how good it is, is still a preliminary study as an introduction to the manuscript, not reviewing the contents. Similar studies have discussed these manuscripts from different perspectives (Farisi 2011; Makmun 2014; Priyatna 2017; Purnamasari 2017; Sukardi 2016). However, studies on the manuscripts and contextualization to the current education are still lacking. This study seeks to contextualize the value of Javanese script character education with the concept of character education in present days.

This study is assumed based on the principle of life-long learning, where the past and present are interconnected. Based on these assumptions, this study argues the following. First, there are always educational values that can be taken and functioned from past work. Second, the past value can be recognized for its benefits through the process of interpretation. Third, the values from the past will be successfully utilized if contextualization is carried out with the present situation. This study seeks to answer three questions: a) how was Suluk Candra manuscript created in terms of the author and the social context; b) what is the content of Suluk Candra when interpreted 
according to theoretical frameworks; and c) how can the character values from Suluk Candra be contextualized with education in era 4.0 which is also based on character values. The three answers to these questions are the subject of each of the parts of this paper.

\section{Literature Review}

\section{A. Character education}

Character is closely related to moral. The simple definition of the word moral is one's knowledge of something good or bad (Hamid 2017). Moral education is the basis of the essential elements of an educational character (Koesoema 2007: 195). Character education is a process of civilizing and transforming human values and Indonesian cultural values in the dynamics of community, nation and state life. Internalization of character values in the realm of education certainly aims to produce young people of good character (Sukiyat 2020: 20).

In Indonesia, character education is not a new phenomenon. The declaration of character education was carried out by Susilo Bambang Yudhoyono on the commemoration of National Education Day 2 May 2010. Until now, character education is still being developed and is the focus of education at all levels of education (Sukiyat 2020: 6). The implementation of character education in Indonesia is very much in line with the goals of national education in shaping the nation's dignified character and civilization. In 2017 Indonesian government VOL. 9 NO. 1 JUNE 2020 
through the Ministry of Education and Culture launched a new policy related to eight hours at school or five school days, in which there is a program to strengthen character education supported by the issuance of Presidential Regulation No. 87 of 2017 regarding the Strengthening of Character Education. Article 1 Paragraph 1 states that the Strengthening of Character Education, hereinafter referred to as PPK, is an educational movement under the responsibility of the education unit to strengthen the character of students through harmonization of heart training, exercise, thought, and sports with the involvement and cooperation between education units, family, and society as part of Gerakan Nasional Revolusi Mental (GNRM). In other words, character education is to synergize the role of the whole community in education (Lickona 2012). Educational and cultural aspects support each other in the development of character education. Character is formed by good morals, and morals are derived from cultural values, especially those that have the support of religious teachings (Simanjuntak 2014).

\section{B. Character and classic manuscripts}

One of the cultural products that can play a role in shaping this character is the classical texts. Understanding ancient manuscripts and the character aspects in it cannot be separated from understanding who the author(s) is and his characters. 
There are at least three indicators to view a figure: integrity (scientific, leadership, or peculiarity owned); monumental works; and contributions (services or effects to the community) (Harahap 2006). It means, examining a manuscript is also examining the writer and social context. A text does not stand alone. It is shaped by the time, place, history, and culture around it. Studying and interpreting a text, as stated by Robson, will be comprehensive if it is not only processing the text, but also is supported by an assessment of the source of the text, the author's background, and the surrounding culture underlying the writing of the text. Text studies will be of high benefit if they are then able to be contextualized (Robson 1994).

One genre of manuscripts that contain character and moral values is the genre of piwulang, also known as didactic literary. Piwulang provides the teaching of the noble values combined with the teachings of early Islam (Maknun 2017).

\section{Interpretation and Contextualization of Value}

Interpretation is another term for "tafsir", the Greek derivation which turns "hermeneutic". This concept is then also used in a review of the text as a method to explain and find out messages from writings that are still unclear and cause confusion to readers. One of the concepts of hermeneutics / interpretation referred to in this study is the perspective of Paul Ricoeur who seeks to uncover the objective meaning of text that 
has a distance of space and time with the reader. In the next stage, in understanding the text does not always try to explore the writer's intention as a reference (Hardiman 2015; WachidB.S. 2006). Robson states that the text of the manuscript does not emerge from a vacuum, but rather there is a condition and situation surrounding and influencing its birth (1994), therefore to comprehend the text comprehensively it is necessary to trace the conditions outside the text. However, after the text can be understood in this way, it does not mean the task of the reviewer ends, because ideally the results of understanding obtained from the text can be applied or contextualized as much as possible to the present situation. Contextualization efforts in Ricouer's perspective try to break away from the author's limited horizons to be open to read and to interpret differently by subsequent readers (Wachid 2006).

\section{Method}

This study employs qualitative design examining Suluk Candra's manuscript written by Prince Wijil Kadilangu located in Museum Reksa Pustaka Mangkunegaran Surakarta library. It is written in Javanese language. This manuscript is analyzed using the principles of philology, translation, and interpretation (hermeneutics). The philological step begins by an approach leading the reviewer to respond to the manuscript (Ikram 2019; Luthfi 2016; Robson 1994). It is followed by the translation of 
Javanese text both lexically and pragmatically, focusing on communicative side of the reader and cultural context (Anis et al. 2016). As this Suluk is in the form of poetry, a further interpretation is also conducted to reveal the symbolic meaning in it (Hardiman 2015). Finally, the translation texts were filtered into themes that contains educational or character values.

\section{Result and Discussion}

\section{A. Suluk Candra: Author and Social Context}

This manuscript was written in the era of King Pakubuwono II where he assigned Prince Wijil as the scriptwriter. Prince Wijil's duty was to be a servant and to carry out his royal command. Based on the Florida's catalog, the places where the manuscript was written were Kartasura and Surakarta. This means that the manuscript was written in the transitional period of the Palace of Kartasura to Surakarta. The text was born in the palace, laden with relations between the King at that time (Pakubuwono II) and the courtiers who were assigned to find the right location for the transfer of the Kartasura Palace, which eventually found the Sala Village (Florida 1993, 2000; Kadilangu 1870; Margapranata \& Etall 1986; Sayid n.d.). According to these sources, Prince Wijil Kadilangu who was referred to as the author of Candra's suluk was Prince Wijil I. Although he was still a descendant of Sunan Kalijaga, Prince Wijil at that time served as a royal servant and 
palace poet who lived during the reign of King Pakubuwono II. In the process of transition of Kartasura Palace to Surakarta, he was assigned by the King to investigate and test whether Sala Village was a suitable place for the Kartasura Palace (Faberiek n.d.).

Sunan Kalijaga is the son of the Regent of Tuban (Ki Tumenggung Wilatikta). He married Dewi Saroh Binti Maulana Ishaq and had a son, Raden Umar Sa'id (Sunan Muria) and two daughters, Dewi Rukayah and Dewi Sofiah (Shihabuddin 2013). The book of Poestoko Darah Agung mentioned that Sunan Kalijaga studied for quite long with Sunan Syarif Hidayatullah Cirebon, and he eventually married Sunan Syarif Hidayatullah's daughter, Dewi Sarokah. From his marriage to Dewi Sarokah, he had five children, one of whom was Sunan Hadi or Panembahan Kali (Prayitno 2010).

Genealogy showing that Prince Wijil Kadilangu is a descendant of Sunan Kalijaga, can be described as hereditary as follows (Faberiek n.d.):

- Sunan Kalijaga had a son named Sunan Hadi/Panembahan Kali

- Sunan Hadi had sons named Panembahan Pengulu and Penembahan Semarang

- Panembahan Pengulu had a son named Panembahan Ketib

- Panembahan Ketib had a son named Panembahan Sabrang

- Panembahan Sabrang had a son named Panembahan 


\section{Notoprodjo}

- Panembahan Notoprojo had a son named Pangeran Wijil

- Pangeran Wijil has five sons, one of whom is Prince Wijil I who died in Lawean Surakarta, he is the author of Serat Suluk Candra. He was married to the daughter of Raden Tumenggung Tjokronegoro Regent of Kedu, and had twenty-one children.

- One of Prince Wijil I's sons named R.B. Wariokoesoemo or R.M. Soedjalmi who lived in the Ngasinan Kedu had sixteen children, who dropped off Kanjeng Pangeran Surjodiningrat in Surakarta.

The writing of Suluk Candra by Pangeran Wijil Kadilangu was carried on in the mid $18 \mathrm{t}^{\mathrm{h}}$ century during the reign of Pakubowono II (reigning in 1726-1749) (Florida 2000). At that time, there was a transition from the Kartasura Palace to the Surakarta Palace led by King Pakubuwono II, who saw the destruction of the kingdom and its residence along with the assets of the whole kingdom. To find a proper place for the transfer of the Kingdom of Kartasura, the King ordered a number of his servants, one of whom was Prince Wijil who was tasked with finding suitable land as a place to live. The other three courtiers were Kyai Kalipah Buyut, Mas Pangulu Pekik Ibrahim, and Kyai Tumenggung Tirtawiguna. From the search of the courtiers, two places were found, namely Talangwangi / Kadipala Village and Sala Village (Prayitno 2010).

10 | VOL. 9 NO. 1 JUNE 2020 
Other sources mentioned that Prince Wijil and the three other servants (Kyai Kalipah Buyut, Mas Pangulu Pekik Ibrahim and Kyai Tumenggung Tirtawiguna) received orders from King Pakubuwono II to investigate carefully whether Sala Village was a proper and prime place for the movement of the Kartasura Palace. Previously, King Pakubuwono had sent several servants in the palace to find a suitable place according to supernatural cues. The envoys were Mayor Hogendorep, Adipati Pringgalaya, and several other regents and courtiers. Their search resulted in three villages deemed appropriate for the transition of the Kartasura Palace, namely Kadipala Village, Sala Village, and Sanasewu Village. From the three villages it was agreed by the king's envoys that Sala Village was worthy of being a new palace place (Margapranata \& Etall 1986).

\section{B. Philological History of Suluk Candra}

The manuscripts of Suluk Candra in the treasury of manuscripts in Surakarta refer to two kinds of manuscript texts. The first text by Arya Jayadiningrat I as stored in the Radya Pustaka Museum contains characters from various ethnicities in Java. This Suluk is a part of Serat Wulang manuscript which is an original handwritten manuscript in which there are four texts: 1) Suluk Mas Nganten, 2) Suluk Margawirya , 3) Suluk Jekrek, and 4) Suluk Candra. The second text of Suluk Candra refers to the work of Prince Wijil Kadilangu generally containing Sufism and Islamic ethics. Studies conducted by researchers were 
related to education-containing manuscripts that can be explored by character education. Therefore, it was the text of the Prince Wijil Kadilangu that is continued for the study, located in the Rekso Pustaka Museum collection. The details of the manuscript is presented below.

Table 1. Comparison of Suluk Candra in Nancy F Catalog 1 and 2

\begin{tabular}{|c|c|}
\hline KS $481.14244 \mathrm{Na}$ & SMP 191/7 \\
\hline $\begin{array}{l}\text { Suluk saking kitab Candra. } \\
\text { (Suluk saking kitab Condra) } \\
\text { Author: Wijil Kadilangu, Pangéran. } \\
\text { Composed: Kartasura; Surakarta, [mid } \\
\text { 18th c.]. } \\
\text { Inscribed: Surakarta, } 1870 . \\
\text { Scribe: Hawikrama, Ng. } \\
\text { MS. pp. 149-84; } 33.2 \times 20.5 \mathrm{~cm} . \\
\text { Religion. Islam - Tasawwuf - Suluk } \\
\text { Didactic literature. Youth } \\
\text { Lessons addressed to youth on the way to } \\
\text { Perfection; Islamic ethics. Macapat verse: } \\
\text { three cantos. Poem opens in } \\
\text { Dhangdhanggula metre: "Éling-élingen } \\
\text { ngagesang bénjing." The teachings } \\
\text { emphasize, among other things, service and } \\
\text { submission to one's king, one's teacher(s), } \\
\text { one's parents, and oneself. Text calls for } \\
\text { adherence to Islamic and state laws. }\end{array}$ & $\begin{array}{l}\text { Serat Suluk Candra } \\
\text { Serat Suluk Condra } \\
\text { Author: Wijil Kadilangu, Pangéran } \\
\text { Composed: Kartasura, Surakarta; mid } \\
\text { 18th c. } \\
\text { Inscribed: Surakarta, [mid-late 19th } \\
\text { c.] } \\
\text { i, } 16 \text { pp.; } 33.5 \times 20.5 \mathrm{~cm} \text {. } \\
\text { Religion. Islam - Tasawwuf -- Suluk } \\
\text { Didactic literature. Youth } \\
\text { Islamic ethics: lessons addressed to } \\
\text { youth concerning the way to Perfection. } \\
\text { Macapat verse. One canto only, in } \\
\text { Dhangdhanggula The poem opens: } \\
\text { "Éling-élingen ngabesang bénjing." End of } \\
\text { MS missing. Authorship is attributed to } \\
\text { Pangéran Wijil Kadilangu, court poet to } \\
\text { Pakubuwana II. } \\
\text { Karaton Surakarta Kadipatèn script. } \\
\text { Watermarks: "VDL"; "PROPATRIA } \\
\text { EENDRAGT MAAKT MAGT." }\end{array}$ \\
\hline Catalog 1 (Florida, 1993: 262) & Catalog 2 (Florida, 2000: 207) \\
\hline
\end{tabular}

The results of the philological identification of this manuscript stored in Rekso Pustaka Pustaka Museum be seen in table 2 below.

Table 2. Description of Serat Suluk Candra by Prince Wijil Kadilangu

\begin{tabular}{|c|c|c|}
\hline No. & Aspect & Description \\
\hline 1. & Title/Theme of Text & Suluk Candra \\
\hline 2. & Genre & Tembang (Dandanggendhis) \\
\hline
\end{tabular}




\begin{tabular}{|c|c|c|}
\hline No. & Aspect & Description \\
\hline 3. & Author & Prince Wijil Kadilangu \\
\hline 4. & Copier & Hawikrama, Ng. \\
\hline 5. & initiator & - \\
\hline 6. & Writing time & Mid $18^{\text {th }}$ century \\
\hline 7. & Copying time & 1870 (Mid-end of $19^{\text {th }}$ century) \\
\hline 8. & Text writing place & Kartasura, Surakarta \\
\hline 9. & Text copying place & Surakarta \\
\hline 10. & Text study done & - \\
\hline 11. & $\begin{array}{l}\text { Text editing done } \\
\text { Editing type } \\
\text { Editor }\end{array}$ & $\begin{array}{l}\text { Transferring Script from JavaneseScript to } \\
\text { Latin Script } \\
\text { Darweni (as manager of ReksoPustaka } \\
\text { Library) in } 1994\end{array}$ \\
\hline 12. & $\begin{array}{l}\text { Text translation done } \\
\text { Title } \\
\text { Translator }\end{array}$ & Not found \\
\hline 13. & $\begin{array}{l}\text { Text editing by the } \\
\text { researchers }\end{array}$ & $\begin{array}{l}\text { Copying the script by Mrs. Darweni, } \\
\text { because the edits that researchers obtained } \\
\text { in the form of hard copies }\end{array}$ \\
\hline 14. & $\begin{array}{l}\text { Text translation by the } \\
\text { researchers }\end{array}$ & $\begin{array}{l}\text { Because there was no translator, the } \\
\text { researcher asked the help of Rekso Pustaka } \\
\text { Library employee to translate. The } \\
\text { translation team was } \\
\text { chaired by Bayun Marsiwi. }\end{array}$ \\
\hline 15. & Summary & $\begin{array}{l}\text { Teachings about ethics to the king,teachers, } \\
\text { fellow, and to yourself. }\end{array}$ \\
\hline 16. & $\begin{array}{l}\text { Manuscript specification } \\
\text { (contains the value of the } \\
\text { uniqueness of the } \\
\text { manuscript) }\end{array}$ & $\begin{array}{l}\text { This text has an element of advice to } \\
\text { comply with Islamic law and state law } \\
\text { (Nancy Catalog Vol. 1). } \\
\text { In this text, the teacher and the king have } \\
\text { the same position and degree, so the ethics } \\
\text { that must be carried out to the king is the } \\
\text { same as the ethics for the teacher. } \\
\text { This text was written during the transitional } \\
\text { period of the Kartasura Palace to the } \\
\text { Surakarta Palace, so that the contents of the } \\
\text { manuscript were inspired by King } \\
\text { Pakubuwono II's task or commandto Prince } \\
\text { Wijil as the scriptwriter, that the duties of } \\
\text { the servant were to be a servant and carry } \\
\text { out his royal command. }\end{array}$ \\
\hline
\end{tabular}

(Source: data collection/ crosscheck by researchers from the Reksa Pustakalibrarys data) 


\section{Transliterated and Translated Edition of Suluk Candra}

Suluk Candra script in Rekso Pustaka Library is a copy of the original one. This script was transliterated into Latin writing by Mrs. Darweni as the manager of Rekso Pustaka Library in 1994. As the original text, transliteration of the Suluk Candra script stopped at verse 66 of Tand Dandanggendis. The continued Candra Suluk script was not found in Rekso Pustaka Library. Transliteration of of Suluk Candra script is 10 pages with 66 stanzas and written with single space. The script has been translated from Javanese by library staffs, therefore the codicological process of the text and the philology of the text are conducted. The researchers here then continued the work due to time constraints and the ability to read and write Javanese script and language. Therefore, with the permission of the library manager, the researcher initiated the process of the language conversion of the Suluk Candra Script which was carried out by a team consisting of three library employees, led by Bayun Marsiwi. In the end, the re-typed edition by the researcher produced 11 pages of the script and language transfer tables with Time New Roman font sized 11 pt.

Examples of the beginning and end of the stanza and the cut off part of the Suluk Candra Script can be seen in table 4 . The text of Suluk Candra is in the form of a Javanese poem that has a standard (its own rules) so that table 3 contains the results of language transfer, editors appear with slash punctuation 
marks (/) as sentence or line separators, and two slashes (//) as movers stanzas.

Table 3. Samples of transliterated scripts

\begin{tabular}{lll}
\hline No. & Transliteration & Translation \\
\hline 1 & Eling-elingen ngagesang Keep in mind that later life / the \\
benjing, ingkang samya kal same state of the world, the \\
dunya, ngakerat, den waspada hereafter / make clear your vision \\
pandulune, lwiring kal / the eternal form of the world / \\
donyanipun, anganggea kawan use four things / the first is \\
prakawis, kang dhingin njih
\end{tabular}

\section{Ethical, Moral, and Character Values of Suluk Candra}

Suluk Candra by Prince Wijil Kadilangu has a moral message closely related to character education. The moral value o f Suluk Candra can at least be divided into four parts, namely ethics to the king, to the teacher, to others, and to yourself. The ethics to the king include: not to be disobedient, not lying, carrying out the king's orders, and serving the king. Teachings about ethics to teachers involve: not to be disobedient, not lying, carrying out the teacher's orders, and 
serving the teacher. Ethical teachings to others include: not lying, not to be jealous, not making fun of others, not being arrogant, to be fair/not to put favoritism, to be patient, and to do good. The teachings about ethics to onself include: not to be stupid, not to daydream, to be honest, not doing adultery, not to be greedy, and to be religious.

In the context of this study, Suluk writers are Javanese aristocrats of the Islamic period, so that the strongest assumption of character and moral values in his work can also be linked to the influence of Islamic religion and Javanese culture. The results of searching for character/ moral values that are close to the values of faith and Islam in Suluk Candra are in abundance. In a discussion of drinking for instance, the form of liquor, the causes of the prohibition, and its impact on the drinker as a person and as a social function are well explained. In this study not all findings are presented, only a few examples and important points that can be presented include in tables 4 and 5 below.

Table 4. Values of Faith Education in Suluk Candra

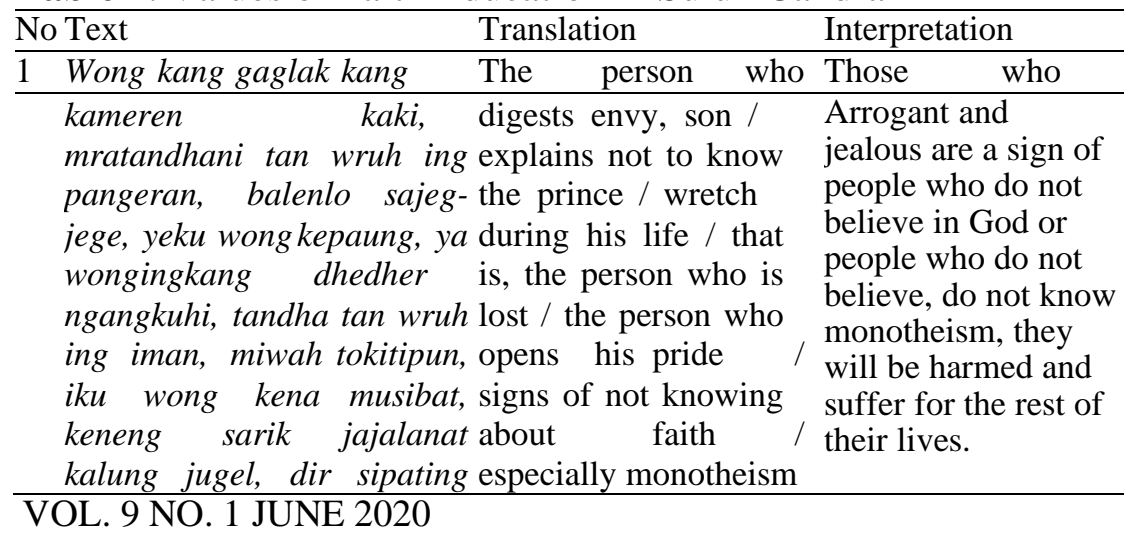




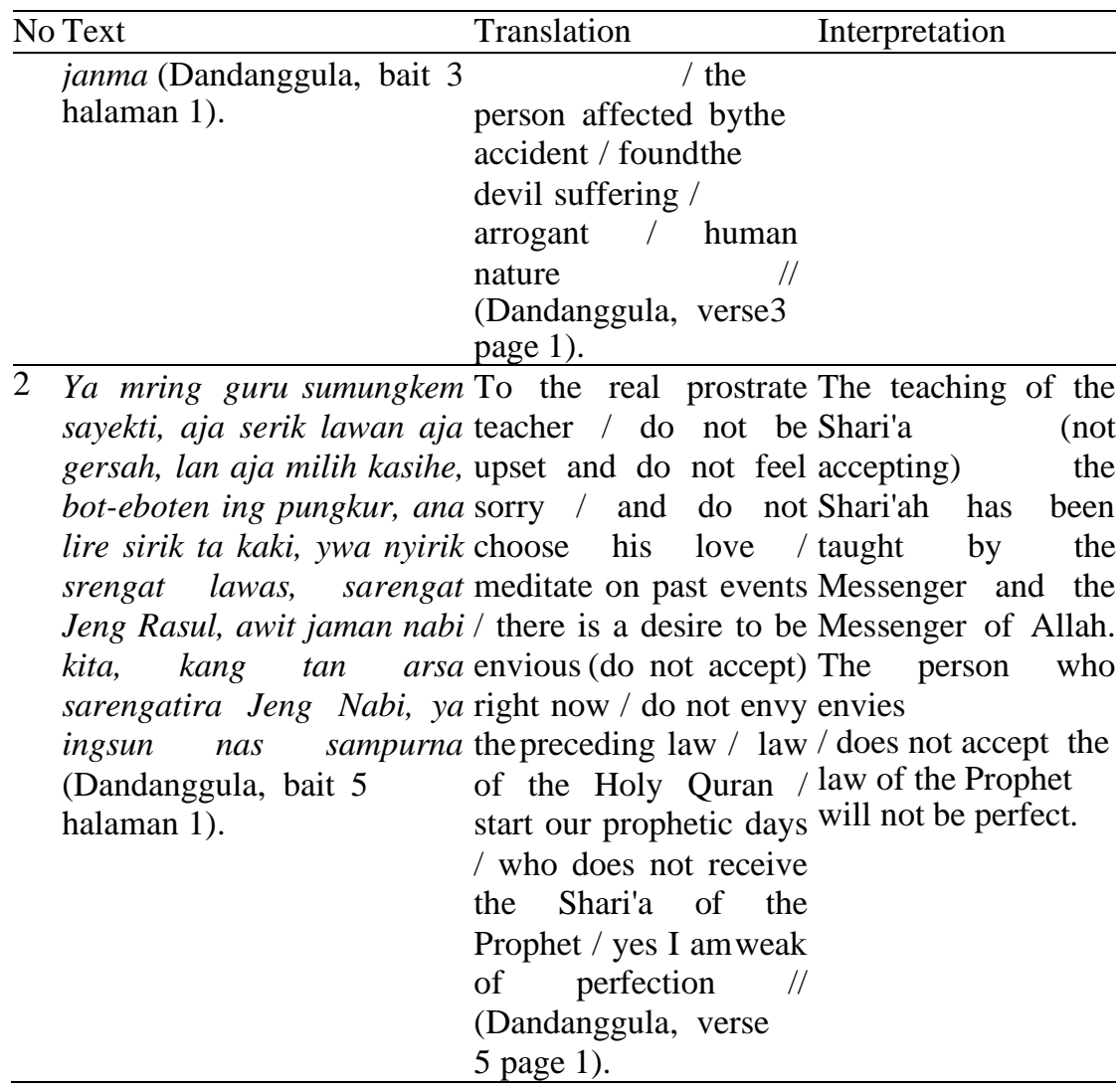

Table 5. Values of Islamic Education in Suluk Candra

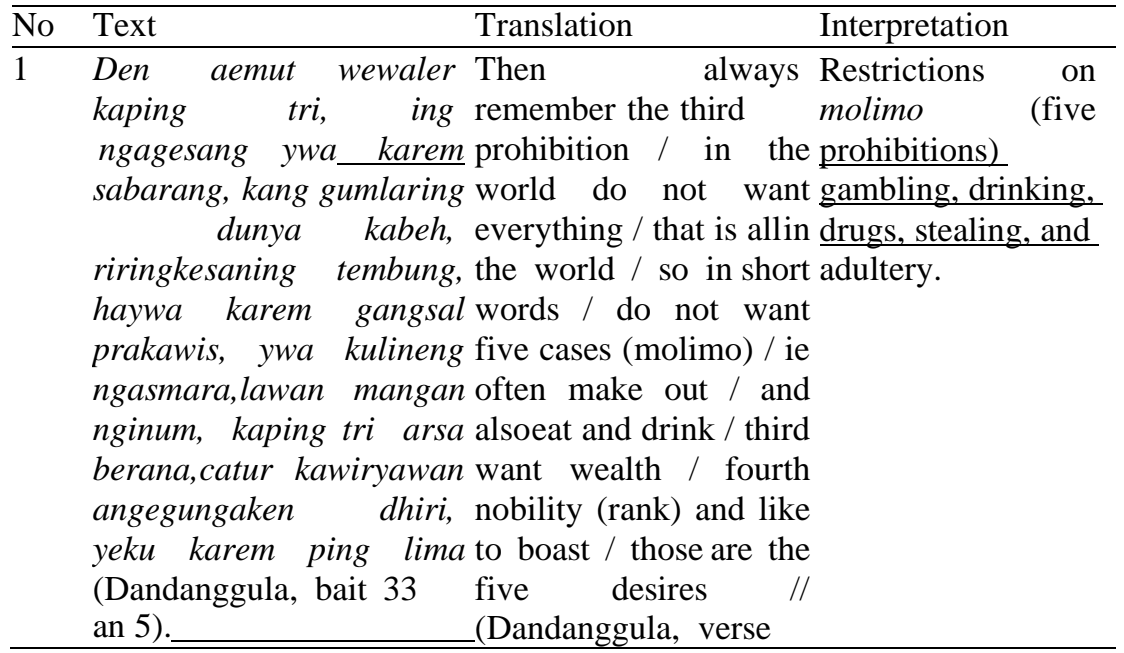




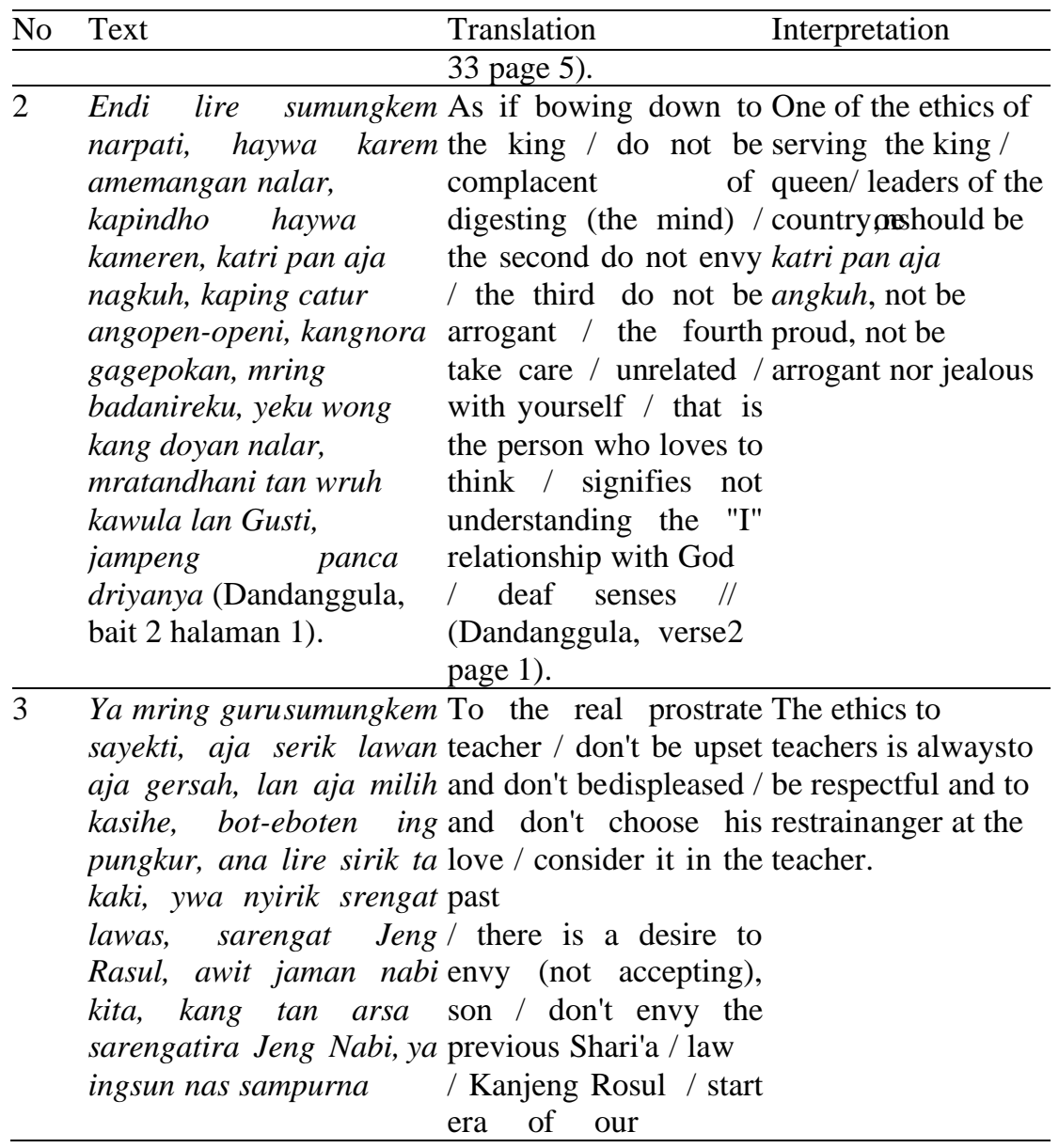

\section{E. Contextualization of Educational Value in Suluk Candra}

The content of Suluk Candra as mentioned above can be contextualized with the present context, including character education. The character values include: the love of science, logic thinking, critical thinking, creative thinking, innovation, religiosity, honesty and nationalism. The love of science can be seen from Dandanggula, verse 13 page 2, which reads:

Kaping tri ywa karem kang dumadi, adining dunya kalawan kerat,

18 | VOL. 9 NO. 1 JUNE 2020 
catur nguni uningane, sastraingkang dumunung, jroning jiwangganireki, kumpule krameng kerat, lawan tubadilun, catur munajat wekasan, eninging ciptamaya den waspadeng ngaksi, sawarga lan naraka.

(Third, do not be complacent by what happens/ the beauty of the world and the hereafter/ the previous word is known /literary is the place/ in your own soul/ the gathering place of the hereafter/ and tubadilun/ the words keep the ending/ silence of the creation note the real/ heaven and hell)

Literature here can be interpreted as kawruh - science, knowledge, through which knowledge can be known the word or previous orders, including the teachings to not to be distracted by beauty of the world. This also means 'awareness', being alert and knowing self.

Values of logic thinking can be seen from Dandanggula verse 1 page 2 , which reads:

Endi lire sumungkem narpati, haywa karem amemangan nalar, kapindho haywa kameren, katri pan aja nagkuh kaping catur angopen- openi, kang nora gagepokan, mring badanireku, yeku wong kang doyan nalar, mratandhani tan wruh kawula lan Gusti, jampeng panca.

As if to prostrate to the king / do not be complacent with your reason (mind) /second, do not be jealous /third, do not be arrogant/ the fourth, do care/ that is not related /with yourself /that is someone who likes to daydream/ not understanding the relationship "I" with God/ (are indeed) deaf of five senses//

This verse mentions people who daydream, yeku wong kang doyan nalar, signifies not understand the relationship with God, as if he was among those who are deaf in five senses. This particular section encourages people to be critical of their own feelings (such as to be rational, to not easily envy, to not be arrogant, etc.). Only when critical thinking is used that someone 
could understand their relationship with God better.

Value of remembering God and following the examples of Prophet is emphasized in the Dandanggula, verse 54 page 9 as follows.

Iku karya bawuring pangeksi, bubrah sagung roh kudus raharja, nuntun mring papa papane, ya jeben den aemut, haywa kongsi lali Hyang Widhi, jaman samengko nora, yen asal wong agung, ambuwang batal lan karam, ngorak-arik sarak sarengating Nabi, jer iku tanpaguna.

(It will disguise the view/ damage all salvation from holy spirit/ lead to disgrace/ then my son remember/ do not forget Hyang Widhi/ donot be like today/ when becoming an authority/ ignore everything that is invalid and unclean/ damage the Shari'a of the Prophet/ it is not useful).

This verse encourages people to be religious by practicing what the Prophet has taught them through the sharia. Religiosity is essential, as without it, knowledge would be useless.

Values of honesty and integrity are discussed in Dandanggula verse 12 page 2 that reads:

Haywa pareg jebeng sira kaki, iku wong akeh sasamarnya, winalik insan kamile, carita kaping catur, sungkemira payitneng janmi, mring jiwangga priyangga, sirnakna kang catur, karana jebeng den yitna, aja ngaku lungguh aneng prang wadani, kapindho aja dora.

(Don't get closer, son/ that's a lot of doubts/ reverse the perfect human/ the fourth story/ your devotion is to be careful to humans/ for your own soul/ destroy the fourth/ so be careful, son/ don't claim to sit on the rug/ second, don't lie)

This verse in particular promotes the ethics associating with others, such as: to be careful and honest (do not lie). Honestly and care are key characters that are promoted by the Character Education movement.

Lastly, the value of nationalism and environment can be 20 VOL. 9 NO. 1 JUNE 2020 
seen in the Dandanggula verse 21 page 4 as follows

Anglakoni dora mring narpati, dadi sira dora triprakara, dhingin mring yayah renane, dosa ping kalih tuhu, dosa marang gusti Jeng Nabi, Rasul nayakaning rat, tri dosa ywang agung, tan wurung asiyasiya, nadyan silih neng dunya prapta ing ngakir, anemu kasangsara.

Commit disobedience to the king/ will make you sinful in three things/ the first sin is to your father and mother/ the second sin is/ a sin to Kangjeng the Prophet who is the world leader/ the third is to sin to $\mathrm{God} /$ therefore it will be in vain/ even though in the world or in the end world later/ will encounter misery//

This verse strongly mentions that a disobedience to the king is like committing three sins to God, to the Prophet and to the parents. The sins are so severe that the perpetrators will get the punishment both in the world and the hereafter. It means that Serat Suluk has emphasized the aspect of nationalism or patriotism, and these values are relevant to the values being promoted in the character education.

\section{Discussion}

The manuscript of Suluk Candra was written by Prince Wijil, a servant of the palace and poet of the Palace during the time of King Pakubuwono II Surakarta. He is known as the descendant of Sunan Kalijaga whose integrity as a poet is recorded in many of his notable works. In addition to Suluk Candra, he wrote several other works namely Suluk Tegesing Aksara Alip, Suluk Wasita Gain Sirullah, and Suluk Besi (Florida 1993). One of his works in the form of serat is History of Empu (Florida 2000). These facts indicate that that Prince Wijil could be classified into the ranks of Javanese poets of the
HERITAGE OF NUSANTARA: 
Surakarta Kingdom.

As a royal poet, the writings of Prince Wijil that appeared in Suluk Candra were also influenced and inspired by his position as a royal figure who had the duty to help guard and favor the king and the kingdom. This can be seen from the contents of Suluk Candra containing a lot of ethical teachings of a royal servant to his king, at which time Prince Wijil Kadilangu had a very large task related to the transition of the palace. Even though Suluk Candra can be said to be nuanced in a "palace centric" vioice closely attached to Javanese and royal values, it was also influenced by Islamic values. Re-understanding the ethical values and character of this manuscript is proven to still be adjusted to the current conditions.

The study findings have analyzed the meaning of texts through the lens of interpretive studies. Interpretatively, Javanese noble values are combined with the values of faith and Islam. Such results also illuminates that there was a harmonious combination between Islamic and Javanese values. This finding is in line with those of Saddhono and Pramestuti (2018) who studied Javanese local wisdom. They mentioned that "Islamic religious values can fill the culture that has been owned by Javanese people since a long time ago. The process of spreading Islam through art by Wali Songo in the past is also successful today. The dissemination process is completed without coercion or elimination of the local wisdom of traditional culture. The 
spread of Islam in Indonesia enriches Indonesian culture". It also supports Wulandari's (2019) findings who examined the integration of religion and culture. She mentioned "Cross culture is something that cannot be denied, as is the case in Javanese society which is very multicultural. Babad Ngayogyakarta Text Hamengkubuwana IV-V records the situation. Careful reading or known as close reading of this text gives a picture of Javanese culture that coexists in harmony with Islam".

Besides Javanese and Islamic wisdom values, character values can also be explored from this manuscript of Suluk Candra text. If it is contextualized with the value of character education promoted by the Ministry of Education through the twenty character values, Suluk Candra manuscript also outlines examples of these character values, including the value of love of science, logical and innovative thinking, religiosity, honesty, and nationalism. It means that, long before character education becomes a national movement or national program, it had been taught and applied by past generations. The cultivation of the main character values in Javanese families is in the family environment, even texts that specifically provide character teachings to children are also widely available (Idrus 2012; Widarwati 2018). Therefore, character values that are ingrained in our treasures can still be applied in the world of education today (Andriani 2015; Maunah 2016; Pujiartati et al 2017; Pujiartati \& Sariyatun 2017; Wardhani \& Muhadjir 2017). 
A further challenge resulting from the interpretation of the value of this manuscript is its wider use in the world of education in the 4.0 era. In the Archipelago National Seminar held in 2019, several experts presented the latest developments related to the manuscript. Mu'jizah (2019) asserted that manuscript studies should move towards interdisciplinary studies so that the benefits gained from exploration of manuscripts can be maximized, for example the combination of the philosophical approach with linguistics, literature, history, and so forth. In the same forum, Sudibyo (2019) also mentioned that research studies also need to follow the changing times, including in the use of electronic media and computerized manuscripts. Whereas, Pudjiastuti (2019) gives an example of manuscript digitalization work which is a necessary thing in the mission of saving the manuscript in the 4.0 era.

Finally, further studies on the character values in the manuscript can be conducted to explore other values that ancient manuscripts contain. The studies can be interdisciplinary, combining several fields at the same time to provide richer perspectives.

\section{Conclusion}

This study concludes that character values are not entirely new, as they are recently promoted in the 2013 national curriculum. Character values have been taught, held, and carried 
out in the previous era, and they are rooted in our nation's identity as in recorded in manuscripts. It means characters, morals, and ethics depicted in manuscripts are contextual and relevant to the present time.

The present study has some limitations, especially in presenting the forms of value contextualization of the manuscript's text. This study encourages reviewers and other researchers to develop and continue studying forms of contextualization of character values based on manuscripts that can be formulated and delivered in a more readily accepted form by the public.

\section{Endnotes:}

${ }^{1}$ Ahmad Baso stated that the Nusantara was not only a representation held by Orientalists as a display case in the museum. (Baso 2019) Achadiati Ikram in an introductory book states that written culture in Indonesia has produced literary wealth in various Nusantara languages.

Henri Chambert Loir adds that there are at least thirteen languages used in Nusantara scripts according to Ikram: Aceh, Malay, Batak,Minangkabau, South Sumatra, Sundanese, Javanese, Madura, Balinese,

Sasak, Makassar, Bugis, and Wolio. Each of the cultural centers in Nusantara develops different written traditions and reflects various characters from local traditions, histories, cultures, and arts that enrich Nusantara cultures. (Ikram 2019)

${ }^{2}$ Presidential Decree No. 87 of 2017 on Strengthening Character Education.

${ }^{3}$ Law No 20 of 2003 on the National Education System.

${ }^{4}$ Reported by kompas.com June 13, 2017.

5 As in Rekso Pustaka Mangkunegaran Library, the manager also HERITAGE OF NUSANTARA: 
makes a separate catalog with a different classification, even though it has been catalogued by Nancy F.

${ }^{6}$ Indonesian Internet Service Providers Association. 2018. Penetration \& Profile of Internet User Behavior in Indonesia. Accessed December 3, 2019 from https://apjii.or.id/survei2018s.

7 The discussion results between the researchers and the script librarians at Radya Pustaka Museum, July 2017.

${ }^{8}$ Information and catalog discussions with Rekso Pustaka librarian, July 2017. There is an interesting addition from Rekso Pustaka librarian that Suluk Candra manuscript text of Prince Wijil Kadilangu in the Nancy F 2 Catalog is written in code $244 \mathrm{Na}$, while in ReksoPustaka it is coded A. 185.

\section{References}

Andriani, Tuti. (2015). "Revitalisasi Naskah Syair: Sebuah Solusi Dalam Pengembangan Kreativitas Mahasiswa untuk Mencintai Budaya Lokal." Jurnal Pendidikan Bahasa dan Sastra 15(1): 2015.

Anis, Muhammad Yunus, Arifuddin, Eva Farhah, and Abdul Malik. 2016. Penerjemahan Bahasa Arab: Teknik Dan Metode Penerjemahan Kalimat Nominal Dan Kalimat Verbal Dalam Bahasa Arab. Surakarta: Program Studi Sastra Arab UNS.

Baso, Ahmad. (2019). “ Angajawi ', or, On Being Muslim Nusantara: The Global Argument for Islam (Ic) Nusantara The Importance of Being 'Jawi .'” Heritage of Nusantara: International Journal of Religious and Heritage 8(1).

Cahyaningrum, Ika. (2012). "Serat Mumelen (Suntingan Teks Dan Kajian Semiotik." Universitas Diponegoro Semarang.

Darweni. (1994). Suntingan Teks Suluk Candra. Surakarta. Faberiek,

Tabaks En Tenoen. Poestoko Darah Agoeng.

Fakhriati. (2012)."Perempuan Dalam Manuskrip Aceh: Kajian Teks Dan Konteks."

Jumantara

3(1).https://www.perpusnas.go.id/magazine detail.php?lang=id\&id=8195.

Farisi, Mohammad Imam. (2011). "Kompetensi Guru Dalam Mewujudkan Pendidikan Berkarakter Dan Berbasis Budaya." Jurnal Teknologi Pendidikan.

26 | Fathurohman, 9 NO. 1 JUNE 2020 
Nusantara." Youtube.com. https://www.youtube.com/channel/ UCxFpnO4EWGU88zo9BCafZyg.

Florida, Nancy K. (1993). Javanese Literature in Surakarta Manuscripts. Volume 1. New York: Southeast Asia Program. Cornell University.

Florida, Nancy K. 2000. Javanese Literature in Surakarta Manuscripts. Volume 2. New York: Southeast Asia Program. Cornell University.

Gunawan. (2019). Mencari Peluang Di Revolusi Industri 4.0 Untuk Melalui Era Disrupsi 4.0. Quency Publisher.

Hamid, Abdulloh. (2017). Pendidikan Karakter Berbasis Pesantren. Surabaya: Imtiyaz.

Harahap, Syahrin. (2006). Metodologi Studi Tokoh Pemikiran Islam. Jakarta: Istiqomah Mulya Press.

Hardiman, F. Budi. (2015). Seni Memahami. ed. Widiantoro. Yogyakarta: Kanisius.

Holil, Munawar. (2019). "Medical Manuscripts in The Nusantara Context." International Review of Humanities Studies 4(1): $508-29$.

Idrus, Muhammad. (2012). "Pendidikan Karakter pada Keluarga Jawa." Jurnal Pendidikan Karakter II(2).

Ikram, Achadiati. (2019). Pengantar Penelitian Filologi. ed. Dewaki Kramadibrata. Jakarta: Masyarakat Pernaskahan Nusantara (Manassa).

Iswanto, Agus. (2015). "Kecenderungan Kajian Manuskrip Keislaman di UIN Syarif Hidayatullah Jakarta." Al-Qalam 21(1).http://www.jurnalalqalam.or.id/index.php/Alqalam/article /viewFile/202/185.

Kadilangu, Pangeran Wijil. (1870). Suluk Candra.

Koesoema, Doni. (2007). Pendidikan Karakter Strategi Mendidikan Anak Di Zaman Global. Jakarta: Grasindo.

Lickona, Thomas. (2012). Educating for Character, Mendidik Untuk Membentuk Karakter Bagaimana Sekolah Dapat Memberikan Pendidikan Tentang Sikap Hormat Dan Tanggung Jawab. Jakarta: Bumi Aksara.

Luthfi, Khabibi Muhammad. (2016). "Kontekstualisasi Filologi Dalam Teks-Teks Islam Nusantara." Jurnal Kebudayaan Islam 14(1): 114-28.

Makmun, H. A. Rodli. (2014). "Pembentukan Karakter Berbasis Pendidikan Pesantren :" Cendikia 12(2).

Maknun, Moch. Lukluil. (2017). "The Education of Javanese 
Characters in Serat Wasitawala." Analisa: Journal of Social Science and Religion 2(2): 214. https://blasemarang.kemenag.go.id/journal/ index.php/analisa /article/view/510.

Margapranata, R. Ng, and Etall. (1986). Tus Pajang. Jakarta: Departemen Pendidikan dan Kebudayaan.

Maunah, Binti. (2016). "Implementasi Pendidikan Karakter Dalam Pembentukan Kepribadian Holistik Siswa." Jurnal Pendidikan Karakter (1): 90-101.

Mu'jizah. (2019). "Naskah Sebagai Sumber Kajian Interdisipliner." In Prosiding Seminar Nasional Naskah Dalam Kajian Antardisplin, eds. Priscila F. Limbong, Munawar Holil, and Mamlahatun Buduroh. Jakarta: Laboratorium Filologi Departemen Ilmu Susastra FIB UI Bekerjasama dengan Masyarakat Pernaskahan Nusantara, Pusat Penelitian Kemasyarakatan dan Budaya FIB UI, Badan Pengembangan Bahasa dan Perbukuan Kementrian Pendidikan dan Kebudayaan, dan Perpustakaan.

Muzayanah, Umi. (2018). "Trend Beragama Remaja Era Milenial: Analisis Perilaku Siswa SMA Di Jawa Tengah.” Fikrah: Jurnal Ilmu Aqidah dan Studi Keagamaan 6(2): 261.

Nasional, Pusat Kurikulum dan Perbukuan Badan Penelitian dan Pengembangan Kementerian Pendidikan. (2011). Pedoman Pelaksanaan Pendidikan Karakter. Berdasarkan Pengalaman Di Satuan Pendidikan Rintisan. Jakarta.

Pertiwi, Dinda. (2018). "Manuskrip Sebagai Informasi Sumber Primer Dalam Keberagaman Dan Peradaban Budaya Bangsa." https://www.kompasiana.com/srisubekti_astadi/5bd27cf612ae9

47bda2da8aa/manuskrip-sebagai-informasi-sumber-primerdalam-keberagaman-dan-peradaban-budaya-bangsa?page=all (May 15, 2020).

Prayitno, Hadi. (2010). "Cerita Sunan Kalijaga." blogspot.co.id.

Primadesi, Yona. (2010). "Peran Masyarakat Lokal Dalam Usaha Pelestarian Naskah-Naskah Kuno Paseban.” Jurnal Bahasa dan Seni 11(2).

Priyatna, Muhammad. (2017). "Pendidikan Karakter Berbasis Kearifan Lokal." Edukasi Islami: Jurnal Pendidikan Islam $5(10)$.

Pudjiastuti, Titik. (2019). "Penelitian Naskah Kalimantan Timur Dan Utara Di Era 4.0." In Prosiding Seminar Nasional Naskah Dalam Kajian Antardisplin, eds. Priscila F. Limbong, Munawar 
Holil, and Mamlahatun Buduroh. Laboratorium Filologi Departemen Ilmu Susastra FIB UI Bekerjasama dengan Masyarakat Pernaskahan Nusantara, Pusat Penelitian Kemasyarakatan dan Budaya FIB UI, Badan Pengembangan Bahasa dan Perbukuan Kementrian Pendidikan dan Kebudayaan, dan Perpustakaan Na, 30-43.

Pujiartati, Renny, Hermanu Joebagio, and Sariyatun. (2017).

"Pembelajaran Sejarah Berbasis Nilai-Nilai Serat Wedhatama Untuk Menumbuhkan Etika Dan Moral Siswa." Yupa: Historical Studies Journal 1(1): 48-62.

Pujiartati, Renny, and Sariyatun. (2017). "Dekonstruksi Nilai-Nilai

Etika Dan Moral Dalam Serat Wedhatama Sebagai Media Pembelajaran Sejarah." In Seminar Pendidikan Nasional: Pemanfaatan Smartphone Untuk Literasi Produktif Menjadi Guru Hebat Dengan Smartphone, Pascasarjana Teknologi Pendidikan FKIP Universitas Sebelas Maret, 431-42.

Purnamasari, Dewi. (2017). "Pendidikan Karakter Berbasis AlQuran.” Islamic Counseling 1(1).

Rahman, Fadly. (2018). "Naskah Kuna Sebagai Sumber Mencecap Jejak Boga Leluhur." In Naskah Nusantara Antara Kekunoan Dan Kekinian, eds. Aditia Gunawan and Ali Akbar. Masyarakat Pernaskahan Nusantara (Manassa) dan Perpustakaan Nasional Republik Indonesia, 173-85.

Robson, S.O. (1994). Prinsip-Prinsip Filologi Indonesia. ed. Kentjanawati Gunawan. Jakarta: RUL.

Saddhono, Kundharu, and Dewi Pramestuti. (2018). "Study of Religious Values Based on Javanese Local Wisdom." ElHARAKAH 20(1): 15-32.

Sayid, R.M. Babad Sala. Alih Bahasa Oleh Darweni Pada Tahun 2001. Surakarta: Perpustakaan Rekso Pustoko Istana Mangkunegaran.

Shanthi, Rini Verary, Jumari, and Munifatul Izzati. (2014). "Studi Etnobotani Pengobatan Tradisional Untuk Perawatan Wanita Di Masyarakat Keraton Surakarta Hadiningrat." Biosaintifika: Journal of Biology \& Biology Education 6(2): 61-69.

Shihabuddin. (2013). Membongkar Kejumudan Menjawab TuduhanTuduhan Wahhabi Salafi. Jakarta: Noura Books.

Simanjuntak, Bungaran Antonius. (2014). "Landasan Teori Dan Reflekasi Korelasi Kebudayaan Dan Pendidikan.” In Korelasi Kebudayaan \& Dan Pendidikan Membangun Pendidikan Berbasis Budaya Lokalí, ed. Bungaran Antonius Simanjuntak. 
Jakarta: Yayasan Pustaka Obor Indonesia.

Sudibyo. (2019). "Menegosiasikan Kembali Filologi Dalam Ranah Ilmu-Ilmu Humaniora." In Prosiding Seminar Nasional Naskah Dalam Kajian Antardisplin, eds. Priscila F. Limbong, Munawar Holil, and Mamlahatun Buduroh. Jakarta: Laboratorium Filologi Departemen Ilmu Susastra FIB UI Bekerjasama dengan

Masyarakat Pernaskahan Nusantara, Pusat Penelitian Kemasyarakatan dan Budaya FIB UI, Badan Pengembangan Bahasa dan Perbukuan Kementrian Pendidikan dan Kebudayaan, dan Perpustakaan Na, 18-30.

Sukaesih, S, Y Winoto, ... A Rusmana - Record and Library, and undefined 2018. (2016). "Preservation Of Ancient Manuscripts As Efforts Building Knowledge Management (The Study of Ancient Manuscripts Preservation Activities By." $E$ Journal.Unair.Ac.Id 2(022): 176-87. https://e-journal.unair. ac.id/RLJ/article/view/7233.

Sukardi, Ismail. (2016). "Character Education Based on Religious Values: An Islamic Perspective." Ta'dib 21(1).

Sukiyat. (2020). Strategi Implementasi Pendidikan Karakter. Surabaya: Jagad Media Publishing.

Suryawan, I Gede Agung Jaya. (2016). "Cegah Kenakalan Remaja Melalui Pendidikan Karakter.” Jurnal Penjaminan Mutu 2(1): 64-70.

Susantio, Djulianto. (2018). "Naskah Kuno Nusantara Diolah Dalam Bentuk Digital Oleh Peneliti Eropa." kompasiana.com. https://www.kompasiana.com/djuliantosusantio/5a6999b1ab12a e43bd15d374/naskah-kuno-nusantara-sebelum-rusak-

didigitalkan- peneliti-eropa (May 15, 2020).

Suwardana, Hendra. (2017). "Revolusi Industri 4.0 Berbasis RevolusiMental." Jati Unik 1(2): 102-10.

Wachid-B.S., Abdul. (2006). "Hermeneutika sebagai Sistem Interpretasi Paul Ricoeur dalam Memahami Teks-Teks Seni." Imaji 4(2): 198-209.

Wardhani, Novia Wahyu, and Noeng Muhadjir. (2017). "Pendidikan Karakter Dalam Serat Tripama Karya Mangkunegara IV." Jurnal Pembangunan Pendidikan: Fondasi dan Aplikasi 5(2): 187-98.

Widarwati, Atika Rosiana. (2018). "Ajaran-Ajaran dalam Serat Wulang Putra (Suatu Tinjauan Sosiologi Sastra)." Universitas Negeri Semarang.

Wirayanti, Made Ayu. (2011). "Konservasi Manuskrip Lontar." Visi 30 | VOL. 9 NO. 1 JUNE 2020 
Pustaka, Edition: Vol. 13 No. 2 - Agustus 2011. https://www. perpusnas.go.id/magazine-detail.php?lang=en\&id=8162.

Wulandari, Arsanti. 2019. "The Integration Of Religion And Culture InThe Preparation of A King Within Babad Ngayogyakarta $\mathrm{Hb}$ IV- V." Heritage of Nusantara: International Journal of Religious and Heritage 9(2): 188-207.

Yulianeta. (2018). "Memperkenalkan Nilai-Nilai Luhur Dalam HikayatRaja Kerang Di Sekolah." in Naskah Nusantara Antara Kekunoan Dan Kekinian, eds. Aditia Gunawan and Ali Akbar. Jakarta: Masyarakat Pernaskahan Nusantara (Manassa) dan Perpustakaan Nasional Republik Indonesia, 241-62.

Zulfitri, MA. (2014). "Perhatian Pemerintah Dan Peran Pustakawan Dalam Pemeliharaan Naskah Kuno." AL-Maktabah 13(1): 8188. 


\section{Attachment: Start and End Pages of Suluk Candra PangeranWijil Kadilangu}

Figure 1 starting page of Suluk Candra

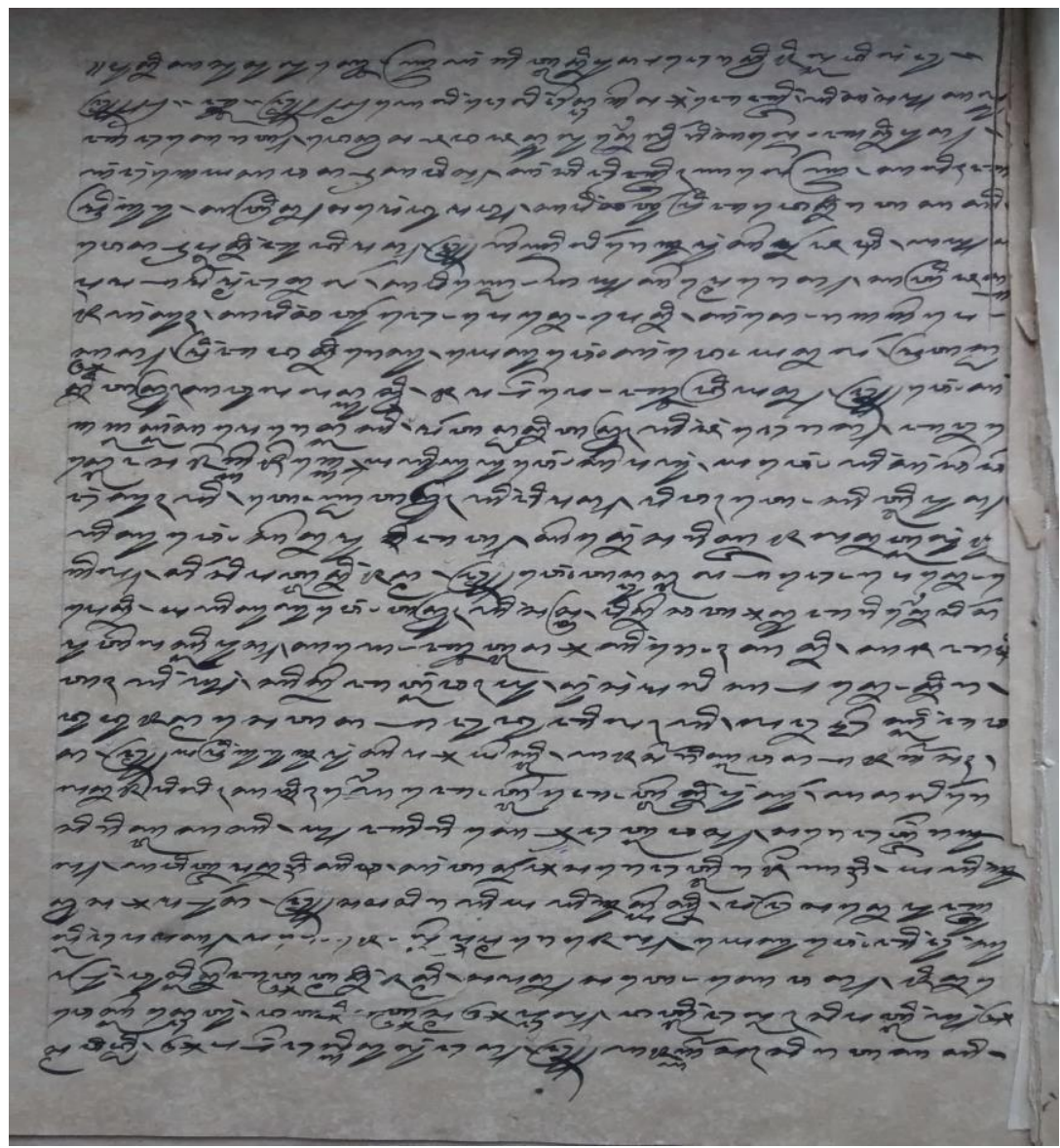

(Source: Researcher's documentation) 
Figure 2 Final page of Suluk Candra

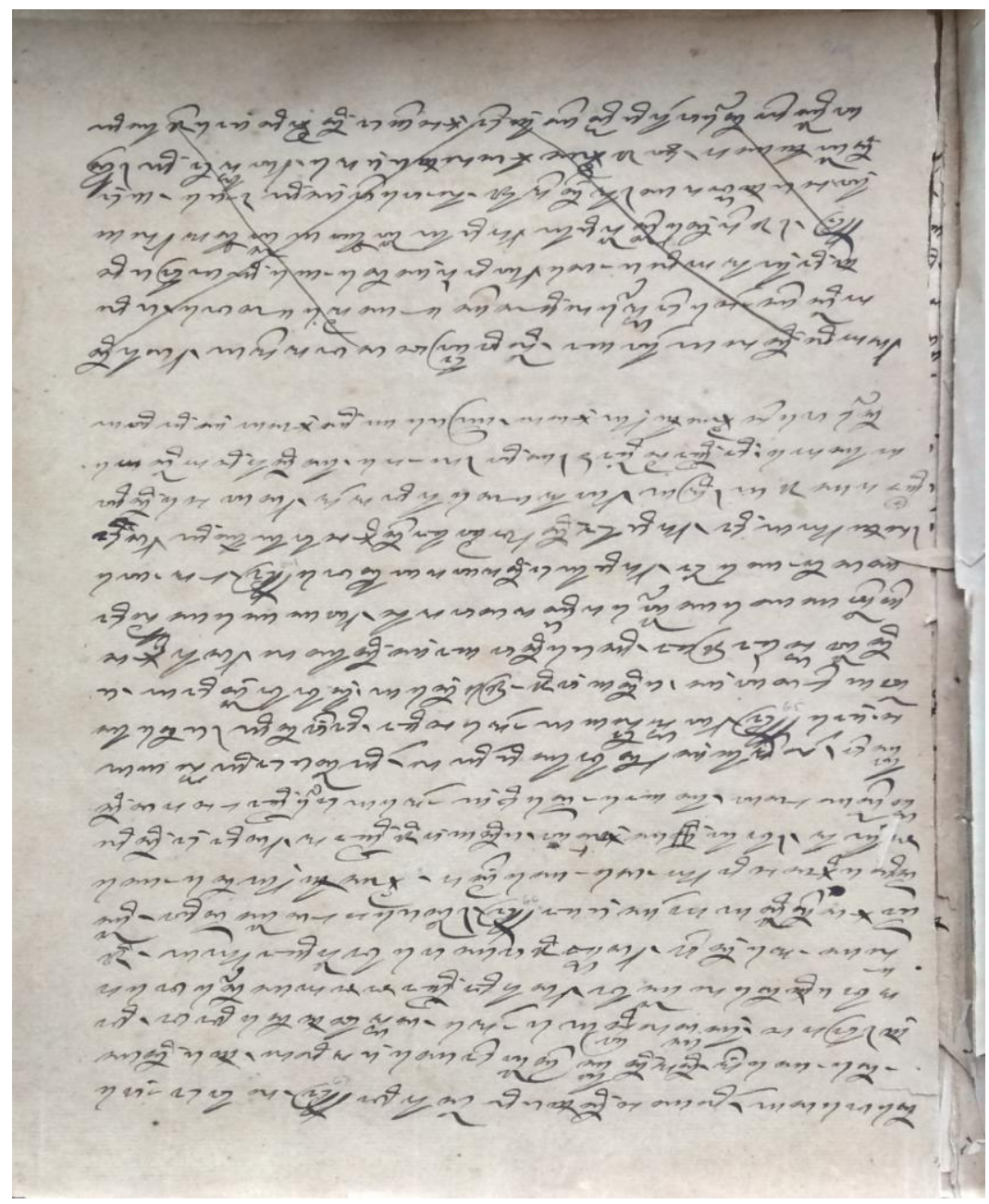

(Source: Researcher's documentation) 